\title{
Port Strategy for Sustainable Development: Circularization and Value Creation-Introduction to a Special Issue
}

\author{
Elvira Haezendonck ${ }^{1,2}$ \\ 1 Faculty of Social Sciences and Solvay Business School, Vrije Universiteit Brussel (VUB), \\ 1050 Brussels, Belgium; elvira.haezendonck@vub.be \\ 2 Faculty of Business Economics, Universiteit Antwerpen (UA), 2000 Antwerp, Belgium
}

Received: 24 November 2020; Accepted: 25 November 2020; Published: 27 November 2020

Today, most large port hubs embrace the circular economy (CE) transformation challenge, and include this together with smart digitalization and the Internet of Things (IoT) in their strategic priorities. The CE transition is particularly challenging because it is complex: ports do not only have to reconsider their own core activities within their port boundaries, but also their role in the supply chain of shippers [1], to lift themselves out of the linear lock-in. Developing business models with allied partners and intensified stakeholder co-creation will be key to this successful strategic change. The articles in this special issue support port strategists and managers by demonstrating and explaining different aspects that ports should consider for their circular economy transformation and advanced sustainability.

Importantly, the $\mathrm{CE}$ transition should not merely be focussing on its potential threat to the volume of handled goods, because CE also creates opportunities for new and different flows. The CE transition is understood to imply shortened and more regional streams of goods, and potentially also inversed material trades [2]. Hence, collaboration and data-exchange with key customers of ports on their change of flows, are crucial to be able to seize these opportunities. In this sense, a successful CE transition of ports implies smart digitalization and more data control on its flows and customers.

However, it also implies financial or business sustainability of this change process. Non-business' (for example government, city, cluster organisations, etc.) initiatives and support are most often behind current circular projects. Much as this support can serve as an engine for innovation towards sustainable port development, in the end port authorities as well as port businesses need to embrace circular learning and turn these projects into sustainable business models, i.e., the design of the value creation, delivery and capture mechanisms employed [3]. Hence, this CE-oriented strategic change requires new insights in innovative governance and business frameworks and further developing the link between strategy and commercially viable business models.

Moreover, ports need to initiate and foster CE-related networks. Through intensified stakeholder collaboration and co-creation, they will together be more powerful in ensuring a business model and form a larger resource pool for developing CE projects and traffic segments.

Finally, ports may have to reconsider their investment policy and landowner role and provide dedicated space, in view of hosting more $\mathrm{CE}$ opportunities and enabling related infrastructure in the area and connection regions. Space for pilot projects, labs and pipelines, among other things, can accelerate the $\mathrm{CE}$ transition. In this context, port alliances and networks need to exploit their synergies for accommodating CE-activities and their mutual benefits from connecting infrastructural links.

\section{Special Issue Content}

This special issue in Sustainability on "Port Strategy for Sustainable Development: circularization and value creation" attracted ten interesting academic papers, which each contribute in 
a particular way to support sustainable port management, and enrich the insights in the domain of port value creation through sustainability and in the rather novel domain of $\mathrm{CE}$.

Basically, the ten contributions of this special issue can be grouped into three themes which they address and study: (1) the importance of metrics and data sharing; (2) the salience of space attribution and organization; and (3) ensuring the survival of $C E$ investments through solid business cases.

Within the first theme, the subjects addressed in five papers are:

1. Measures of port value creation and corporate sustainability (CS) metrics: a rigorous CS measurement framework is developed.

2. Emission control policy and use of accurate data as key to reduce emissions in ports and the air quality of neighbouring residential areas.

3. Better manoeuvring of captains and pilots in ports, given appropriate training and knowledge transfer, can substantially reduce emissions in port areas.

4. Circular supply chains and role of secondary ports depend on data sharing and coordination, among others, and is negatively affected by the linear mindset of port authorities. In secondary ports, stevedores play a key role in developing circular supply chains.

5. Disclosure of data to stakeholders and sustainability reporting for inland ports: expected content of reports is viewed differently for various stakeholders and should unite all views to create a transparent account of the contributions of ports.

The second topic is studied in three papers, on:

1. The importance of less focus on 'negative' CE operational capacity, such as landfills and incinerator capacity: a cap in this capacity encourages port cities to become more circular.

2. Managing port-city distances and in-between areas in a coordinated way is critical to the capacity enhancement and sustainable and ecological development of both ports and cities.

3. Port design and flexible space is important to minimize the impact of road traffic in ports, and simulation can be used for more sustainable 'green' port master planning.

The third topic is specifically addressed in one paper on the business model of port authorities to engage in and foster $\mathrm{CE}$, usually involving new logistical (but fewer international) services that create input-output synergies, and industrial ecology synergies.

Finally, one paper covers all three topics in one: mapping CE initiatives in different port settings and hence benchmarking the $\mathrm{CE}$ project portfolios, based on available data, their location or territorial interaction, and the budget and subsidies involved.

\section{Suggestions for a Future Research Agenda}

While these special issue articles address current CE transition concerns, such as first strategic changes towards circular ports, building awareness on the importance of sustainability data and available space, and how port authorities can develop circular business models, several areas remain open to further research.

1. Considerable resources and funding are currently attributed to the $C E$ transformation of ports. But how does the $\mathrm{CE}$ investment pay off? Ports need to measure and monitor the performance of their CE activities. The development of an optimal monitoring system, a "CE dashboard" including the regular measurement of value added, jobs, return on investment, emission reduction, etc., could serve internal and external reporting, and investment valuation. In addition, this monitoring should provide feedback on missing links and/or processes. This is certainly a promising future research endeavour.

2. In the short term, measuring the direct value added and jobs of CE efforts and CE-dedicated space developments is meaningful for port authorities, policy makers and stakeholders. Given the frequent opposition to the expansion of port capacity in terms of the societal costs versus benefits, 
any changing strategy towards CE should prepare for these broader economic effects as soon as possible.

3. Given most CE initiatives are heavily funded or subsidized, it is salient to study how and with whom these projects can become a new business line for port firms as well as for port authorities. What is in it for whom, and how can port authority business models embed CE in their renewed and more comprehensive business model?

4. Alliances and networks have been pointed out as enabling mechanisms and relationships to accelerate circularity in ports. But how inter-port collaboration and stakeholder co-creation should be organised and how it effectively impacts the transition is currently under-researched.

5. Another future stream of research should establish an integrated sustainability strategy for port managers, reconciling their current corporate social responsibility (CSR) projects such as solar and wind turbine projects, their modal shift ambitions, and their CE transition projects. There may in fact be potential trade-offs complicating this integrated strategic focus. For example, when ports try to shift cargo from road to rail transport, they encourage cargo bundling over longer distances so as to make rail transport a viable alternative. However, the CE transition of ports may imply shorter, more regional and local flows of goods, which may then become, because of their inherent shorter distances, less economically favourable when using environmentally friendly modes of transport.

6. As a final reflection of this editorial, some intriguing research questions can be obtained from a governance perspective: What is the role of each actor in a CE coalition; and how are the ambitions aligned among partners and in relation to their competences and their infrastructure and space capacity?

Funding: This research received no external funding.

Conflicts of Interest: The author declares no conflict of interest.

\section{References}

1. de Langen, P.; Sornn-Friese, H. Ports and the circular economy. In Green Ports; Elsevier: Amsterdam, The Netherlands, 2019; pp. 85-108.

2. Fusco, G.L. Toward a smart sustainable development of port cities/areas: The role of the "Historic Urban Landscape" approach. Sustainability 2013, 5, 4329-4348. [CrossRef]

3. Teece, D.J. Business models, business strategy and innovation. Long Range Plan. 2010, 43, 172-194. [CrossRef]

Publisher's Note: MDPI stays neutral with regard to jurisdictional claims in published maps and institutional affiliations.

(C) 2020 by the author. Licensee MDPI, Basel, Switzerland. This article is an open access article distributed under the terms and conditions of the Creative Commons Attribution (CC BY) license (http://creativecommons.org/licenses/by/4.0/). 